\title{
KEBIJAKAN WAR ON DRUG PRESIDEN DUTERTE: PELANGGARAN HAM DAN TANGGAPAN MASYARAKAT FILIPINA
}

\author{
Hendra Maujana Saragih ${ }^{1 *}$, Anisa Prayuningsih ${ }^{1}$ \\ ${ }^{1}$ Program Studi Hubungan Internasional, Universitas Nasional \\ Email: hendramaujana@gmail.com, anisaprayu@gmail.com. \\ *Korespondensi: hendramaujana@gmail.com.
}

(Submission 25-08-2021, Revissions 13-09-2021, Accepted 21-09-2021)

\begin{abstract}
The Philippines is one of the countries with a fairly high number of drug crimes. The high number of drug crimes has prompted President Rodrigo Duterte to make a war on drugs policy for anyone involved in drug crimes, whether users, dealers and even big dealers. The way this policy works is by shooting dead on the spot for the perpetrators. This has led to serious human rights violations in the Philippines. In this study used qualitative research methods using library research methods. The theory used in analyzing this research is the theory of human rights, the concept of national interest and the concept of transnational crime. The purpose of this study is to explain how the Filipino people respond to the policies set by Rodrigo Duterte. This policy proves that the crime rate has decreased, this is also driven by the trust of the Filipino people.
\end{abstract}

Keywords: war on drug, transnational crime, human rights violations, Filipino people, Rodrigo Duterte.

\begin{abstract}
Abstrak
Fillipina menjadi salah satu negara dengan kasus tindak kejahatan narkoba yang cukup tinggi. Tingginya angka kejahatan narkoba ini mendorong Presiden Rodrigo Duterte untuk membuat kebijakan perang terhadap narkoba bagi siapa saja yang terlibat dalam kejahatan narkoba, baik pemakai, pengedar bahkan bandar besar. Cara kerja kebijakan ini dengan menembak mati di tempat bagi pelaku. Hal ini memicu adanya pelanggaran hak asasi manusia berat di Filipina. Dalam penelitian ini digunakan metode penelitian kualitatif dengan menggunakan metode library research. Teori yang digunakan dalam menganalisis penelitian ini adalah teori hak asasi manusia, konsep kepentingan nasional dan konsep kejahatan transnasional. Tujuan dari penelitian ini adalah untuk menjelaskan bagaimana tanggapan masyarakat Filipina atas kebijakan yang ditetapkan oleh Rodrigo Duterte. Dari kebijakan ini membuktikan bahwa tingkat kriminalitas menurun, hal ini juga didorong dengan adanya kepercayaan masyarakat Filipina.
\end{abstract}


Kata Kunci: perang narkoba, kejahatan transnasional, pelangaran hak asasi manusia, masyarakat Filipina, Rodrigo Duterte.

\section{PENDAHULUAN}

Globalisasi telah membuat negara-negara terhubung dengan mudah melalui perkembangan teknologi dan informasi. Begitu juga dengan tindakan kejahatan yang selama ini berkembang, bukan hanya berada dalam suatu wilayah di satu negara saja, tetapi sudah melewati batas-batas wilayah dengan negara-negara lain. Kejahatan lintas batas negara ini disebut sebagai kejahatan transnasional. Perserikatan Bangsa-Bangsa (PBB) menyatakan kejahatan transnasional sebagai pelanggaran yang mengakibatkan dampak langsung atau tidak langsung yang melibatkan lebih dari satu atau banyak negara.

Kejahatan transnasional yang paling banyak terjadi dan menyangkut masa depan generasi bangsa, terutama generasi muda adalah kejahatan penyalahgunaan obat terlarang yaitu narkotika. Peredaran dan perdagangan narkotika dapat mudah diakses di batas-batas negara melalui jaringan manajemen yang rapi dengan teknologi yang canggih (Anthony, 2009). Penyalahgunaan narkoba menjadi salah satu permasalahan yang sering terjadi di seluruh bagian dunia.

Narkoba (Narkotika dan Obat-obatan Berbahaya) adalah suatu zat yang apabila dihisap, dihirup, diminum, disuntikan atau ditelan akan berpengaruh pada tubuh manusia terutama kerja otak sehingga akan menyebabkan gangguan kesehatan fisik, psikologis dan fungsi sosialnya karena zat ini meyebabkan rasa candu dan ketergantungan. Berdasarkan jenisnya narkoba menyebabkan perubahan pada pikiran, perubahan pada suasana hati dan perubahan perilaku (Martono \& Joewana, 2008).

Filipina menjadi salah satu negara dengan perdagangan dan pengedaran narkoba yang cukup tinggi di kawasan Asia Tenggara, Asia Timur dan Oceania. Kejahatan ini berkembang karena dipicu oleh keadaan perekonomian masyarakat, terutama masyarakat yang tinggal di kawasan kumuh. Masyarakat yang tidak dapat memenuhi kebutuhan hidupnya terpaksa mengambil jalan menjadi pengedar narkoba. Selain itu, harga narkoba seperti sabu, yaitu sebuah varian dari methamphetamine (stimulan yang dapat mempengaruhi sistem saraf pusat) cukup terjangkau. Obat ini berwarna putih, berwujud serbuk kristal yang mudah larut dalam alkohol atau air, tidak berbau dan terasa pahit, biasanya dikonsumsi dengan dihisap melalui hidung, disuntik, ditelan atau dibakar seperti rokok, memudahkan penggunanya untuk mendapatkan barang ini. Jenis narkoba ini bahkan dijuluki sebagai kokain kaum miskin.

Saat maju sebagai calon presiden Filipina, Rodrigo Duterte dalam kampanye menegaskan akan memberantas pengguna dan pengedar narkoba, menurunkan tingkat kemiskinan dan memberantas kriminalitas. Kampanye tersebut mendapat berbagai respon masyarakat Filipina serta harapan bahwa Duterte dapat membawa energy baru bagi Filipina. Hasilnya, Duterte unggul dalam pemilihan presiden. Pada tanggal 30 Juni 2016, di hari pelantikannya, Presiden Duterte menyatakan bahwa siapapun yang terlibat dalam kejahatan narkoba akan menemui kematiannya. Pada 
hari pelantikan sebagai Presiden Filipinan tersebut, Duterte langsung menetapkan Kebijakan War on Drugs yang dilaksanakan berdasarkan Command Memorandum Circular (CMC) No. 16 - 2016 mengenai PNP Anti-Illegal Drugs Campaign PlanProject: "Double Barrel".

Memorandum tersebut merupakan kerangka kerja kampanye Presiden Rodrigo Duterte, yaitu double barrel project yang memiliki dua cabang (Drug Archive), yaitu Oplan Tokhang dan Oplan High Value Target (HVT). Melalui kebijakan ini Presiden Duterte menyerukan kepada petugas kepolisian untuk menembak mati para tersangka narkoba yang dalam operasi melawan petugas. Kebijakan ini berhasil mengurangi kasus terkait narkoba hanya pada kurun waktu satu bulan setelah Duterte dilantik sebagai Presiden. Tetapi kebijakan ini merupakan sebuah pelanggaran Hak Asasi Manusia (HAM) yang berat. Karena kebijakan ini menyebabkan pembunuhan di luar proses hukum, sehingga menyebabkan banyaknya kematian pada pelaku, pengguna dan pengedar tindak kejahatan narkoba yang masuk dalam kategori pelanggaran terhadap Hak Asasi Manusia.

Dalam kerangka ini, penulis melihat tiga isu penting dalam kebijakan War on Drugs Presiden Duterte tersebut, yaitu adanya peredaran narkoba sebagai kejahatan transnasional yang mengancam lingkungan kehidupan nasional dan internasional, adanya kepentingan nasional pemerintahan Filipina untuk memberantas narkoba, dan persoalan menyangkut pelanggaran Hak Asasi Manusia dalam menerapkan kebijakan pemberantasan narkoba. Di sisi lain, terdapat juga tanggapan masyarakat Filipina sebagai pihak yang merasakan atau menerima dampak langsung dari kebijakan tersebut.

Berdasarkan pemikiran ini, maka penelitian ini disusun untuk mengkaji dua rumusan pertanyaan pokok, yaitu: Apa bentuk nyata kebijakan War on Drugs Presiden Duterte pada kejahatan transnasional peredaran narkoba dalam kerangka kepentingan nasional Filipina, serta bagaimana tanggapan warga Filipina atas pelanggaran Hak Asasi Manusia dalam penerapan kebijakan War on Drugs tersebut?

\section{Hak Asasi Manusia}

Filsuf Robert Nozick dan John Rawls (Yesaya, 2017) memandang individu sebagai agen rasional yang diberkahi dengan kebebasan, kesadaran diri dan menentukan bagaimana ia akan hidup yang di dalam dirinya terdapat martabat yang inharen, yang dimana setiap individu tidak bisa diperlakukan semena-mena layaknya suatu benda, mereka tidak boleh dikorbankan atau dimanfaatkan untuk mencapai persetujuan lainnya tanpa mendapat persetujuan dari individu itu sendiri. Setiap individu memiliki hak yang juga berguna sebagai batasan terhadap tindakan atau perlakuan antar individu. Gagasan ini menegaskan bahwa terdapat hal-hal yang yang tidak dapat dicampuri individu atau kelompok lainnya.

Perkembangan Hak Asasi Manusia sejak abad pertengahan hingga kini, tidak menutup kemungkinan terjadi adanya pelanggaran hak asasi manusia. Negaranegara di Dunia ini telah menerima dan menyepakati instrument-instrumen yang terdapat pada hukum internasional yang mengatur terkait hak asasi manusia, International Convenant on Civil and Political Rights dan Universal Declaration of 
Human Rights yang menyatakan bahwa untuk menegakan HAM, maka setiap negara harus menjamin HAM yang dimiliki pada setiap warganya termasuk menghormati, melindungi dan memenuhi. Bahkan, pada pasal 6 ayat 1 yang dinyatakan dalam ICCPR menyebutkan bahwa tidak ada dari setiap manusia yang dapat merenggut hak untuk hidup yang dimiliki setiap manusia lainnya secara sewenang-wenang. Hak yang telah melekat pada manusia dari sejak di kandungan wajib dilindungi oleh hukum (United Nations Human Rights, n.d.). Karena itu, termasuk di dalam pengertian ini adalah hukuman mati dengan menembak di tempat tersangka tindak kejahatan pun, sangat berkaitan dengan hak hidup seseorang.

\section{Kepentingan Nasional}

Dalam pandangan Hans J. Morgenthau (Suwarman, 2018) perilaku negara dalam menjalin hubungan internasional merupakan upaya untuk menjaga agar elemen kekuatan yang dimiliki suatu negara dapat menjamin kedaulatan negara itu, diantara negara-negara lain dan guna menjaga tatanan kekuatan politik di dunia internasional tetap seimbang. Kesamaan kepentingan nasional antara negara satu dengan yang lainnya adalah sama-sama ingin mencapai kelangsungan hidup yang baik, kebutuhan wilayah serta kesejahteraan bagi rakyatnya. Karena itu, dalam setiap tindakan yang dilakukan oleh aktor mempunyai tujuan dan dilatarbelakangi oleh kepentingan Nasional.

Kepentingan Nasional menurut Paul Seabury adalah konsep kepentingan nasional secara normative dan deskriptif. Normative yang dimaksud adalah kepentingan nasional dengan melakukan hubungan luar negeri agar tercapainya citacita suatu bangsa tersebut. Sedangkan secara deskriptif kepentingan nasional adalah tujuan yang harus dicapai malalui kepemimpinan pemerintah.

\section{Transnational Crime}

Kejahatan lintas batas negara merupakan suatu bentuk kejahatan yang dapat membahayakan dan mengancam kepentingan yang dilindungi oleh suatu negara yang dilakukan lebih dari satu wilayah hukum. Menurut (Passas, 2003), Kejahatan Transnasional juga merupakan salah satu ancaman keamanan manusia terbesar, dalam ancaman tersebut termasuk perbudakan, perdagangan manusia, perdagangan senjata internasional, kejahatan lingkungan, terorisme, perdagangan obat terlarang dan lainnya. Kejahatan ini menjadi tantangan bagi hukum, pembangunan social ekonomi, keamanan dan perlindungan hak asasi manusia, pasalnya kejahatan transnasional ini bersifat lintas batas negara. Karena sifatnya yang lintas batas, maka kejahatan ini memerlukan upaya pencegahan dan mengurangi adanya kejahatan transnasional, mengingat hal ini dapat menyebabkan terganggunya keamanan baik nasional maupun internasional juga perlunya kerjasama secara regional maupun internasional dengan cara bertukar data ataupun informasi.

Salah satu bentuk kejahatan transnasional yang mengancam keamanan manusia dan nasional adalah mudahnya arus perdagangan narkotika melewati batasbatas negara melalui pengaturan dan teknologi yang canggih. Pengedaran narkotika menjadi perhatian yang serius bagi negara-negara di dunia. Menurut laporan 
ASEAN Narco Center pada tahun 2016 (Prayuda, 2020), di Filipina terdapat sebanyak $1.429 .474 \mathrm{~kg}$ ganja dan $0,022 \mathrm{~kg}$ heroin dalam bisnis penyelundupan narkotika. Salah satu yang menjadi faktor utama seseorang mengedarkan narkoba adalah karena kemiskinan.

\section{METODE}

Penelitian ini menggunakan pendekatan penelitian kualitatif. (Saryono, 2010) menyebutkan bahwa penelitian kualitatif adalah penelitian yang digunakan untuk menemukan, menyelidiki, menggambarkan dan menjelaskan keistimewaan atau kualitas dari adanya pengaruh sosial yang tidak dapat dijelaskan, digambarkan maupun diukur melalui pendekatan kuantitatif. Sedangkan menurut (Meleong, 2014), penelitian kualitatif merupakan penelitian yang dimaksudkan untuk memahami fenomena mengenai subyek penelitian, seperti motivasi, persepsi, perilaku, maupun tindakan dengan cara deskripsi dalam bentuk Bahasa pada konteks khusus yang alamiah dengan memanfaatkan berbagai metode alamiah.

Pengumpulan data untuk penelitian kualitatif menggunakan berbagai teknik pengumpulan secara gabungan, kemudian dalam menganalisis datanya didasari dari fakta-fakta yang ditemukan di lapangan dan dibangun menjadi sebuuah teori dan hipotesis. Untuk mendapatkan suatu data yang mendalam, maka digunakan metode penelitian kualitatif, sehingga data tersebut mengandung makna. Makna dalam metode penelitian ini merupakan data yang sebenar-benarnya (Sugiyono, 2017).

Melalui metode penelitian kualitatif ini, penulis menjelaskan kebijakan Presiden Duterte terkait tindak kejahatan Narkoba di Filipina sebagai suatu studi kasus. Alasan digunakan studi kasus adalah karena adanya pelanggaran Hak Asasi Manusia (HAM) yang cukup berat tanpa adanya pengadilan terlebih dahulu, hal ini juga memicu adanya warga sipil yang membunuh warga lainnya dengan motif lain tetapi motifnya dibuat seolah-olah pelaku tindak kejahatan narkoba.

Dalam pengumpulan data, penulis menggunakan metode library research dimana pengumpulan data dilakukan untuk mendukung argumen dengan cara mengumpulkan data tersebut dari berbagai sumber seperti buku atau literatur, jurnal, surat kabar, majalah maupun internet. Teknik pengolahan dan analisis data yang digunakan penulis adalah dengan reduksi dan display data. Reduksi yaitu merupakan penyederhanaan dan menyaring data yang tidak diperlukan sehingga data atau penelitian tersebut dapat menghasilkan informasi yang bermakna dan memudahkan penarikan kesimpulannya.

\section{PEMBAHASAN}

International Narcotics Control Strategy Report (INCSR) menyatakan bahwa ancaman serius bagi nasional dan internasional adalah perdagangan narkoba yang berada di luar jalur hukum. Negara yang memiliki ancaman serius ini salah satunya adalah Filipina, yang menjadi negara dengan urutan kelima sebagai negara produsen sabu terbesar di kawasan Asia Tenggara, Asia Timur dan Oceania untuk jenis marijuana (World Drugs Report, n.d.). Filipina yang mempunyai letak 
geografis yang berbatasan dengan Samudera Pasific di sebelah Utara dan Timur, di sebelah Barat berbatasan dengan Laut Cina dan di sebelah selatan berbatasan dengan Laut Sulawesi (Geografi Org, n.d.) menjadi hambatan bagi pihak yang berwenang dalam mengatasi dan mengawasi tindak kejahatan narkoba di Filipina.

Di sisi lain, masalah serius yang dihadapi Filipina adalah tingginya tingkat kriminalitas, yang terjadi karena didorong oleh kemiskinan. Kriminalitas seperti perampokan dan kekerasan menjadi bentuk kejahatan paling banyak terjadi di masyarakat Filipina. Pada tahun 2012 dilaporkan terdapat 217 ribu tindak kriminalitas yang terjadi, sedangkan pada tahun 2014 terdapat 1,16 juta kasus kriminalitas yang dilaporkan. Hal ini menunjukan adanya peningkatan hampir 500\% terjadinya kriminalitas (Yudhistira, 2016). Akibatnya, masyarakat dihantui dengan ketakutan dan membuat harapan akan adanya pemimpin yang mampu memberantas pelaku tindak kejahatan.

Sebelum terpilih menjadi Presiden Filipina, Rodrigo Duterte adalah Walikota Davao yang terletak di Pulau Mindanao. Duterte menduduki jabatan tersebut selama 22 tahun sehingga menjadi walikota terlama di Davao. Pria yang lahir pada 28 Maret 1945 ini berhasil mengubah kota yang tadinya menjadi surga bagi para pelanggar hukum, menjadi kota yang penuh kedamaian. Keberhasilan Duterte dalam menerapkan kedisiplinan warga sipil di Kota Davao terasa kontradiktif, contohnya seperti larangan merokok dan minuman keras di area publik. Kepercayaan rakyat kepada Duterte meningkat karena kemampuan dalam menjaga keamanan, menekankan kriminalitas, pembangunan infrastruktur, mendorong pembaruan kota dan efisiensi administrasi. Hal ini yang menjadikan Kota Davao saat ini sebagai kota yang aman dan ramah bisnis (Internasional Kompas, 2016).

Pada akhir tahun 2015, Duterte mencalonkan diri dalam pilpres Filipina tahun 2016 dan Duterte terpilih menjadi Presiden Filipina. Terpilihnya Rodrigo Duterte menjadi Presiden Filipina, menjadi jawaban atas kekhawatiran masyarakat Filipina. Duterte telah menjadi pejabat yang dianggap sukses karena berhasil menciptakan ketentraman di Kota Davao dimana hal ini menjadi harapan baru bagi masyarakat Filipina. Masyarakat Filipina yakin bahwa Duterte akan menindak secara tegas terkait permasalahan narkoba dan tindakan kriminalitas.

Setelah pelantikannya, Duterte secara terang-terangan menyatakan keinginan untuk membantai tindak kejahatan illegal drugs. Menurut Duterte, candu terhadap narkoba dan perdagangan narkoba merupakan hambatan utama bagi majunya perekonomian di Filipina. Sistem peradilan pada pemerintahan sebelumnya, yang dianggap lambat mendorong Duterte untuk bertindak secara proaktif dengan mengatasi persoalan narkoba dengan cara yang tidak konstruktif, yaitu pelanggaran hak asasi manusia (Xiu, 2016). Keinginannya tersebut kemudian dibuktikan pada hari pertama dilantik sebagai Presiden Filipina. Duterte yang menjabat sebagai Presiden Filipina sejak 1 Juli 2016, langsung menetapkan kebijakan War On Drugs yang dilaksanakan berdasarkan Command Memorandum Circular (CMC) No. 16 - 2016 mengenai PNP Anti-Illegal Drugs Campaign PlanProject: "Double Barrel". 
Dalam kerangka konsep kepentingan nasional, hal ini menunjukan bahwa Presiden Rodrigo Duterte menggunakan kekuasaannya dalam upaya mencapai kepentingan nasional Filipina. Hal ini juga berkaitan dengan kapabilitas suatu negara dimana kekuasaan memiliki peran yang penting dalam menjalankan strategi untuk mencapai kepentingan nasional. Karena dalam kebijakan perang terhadap narkoba, terdapat nilai-nilai kepentingan nasional yang ingin dicapai Rodrigo Duterte, yaitu kepentingan sosial ekonomi dan politik yang diharapkan dapat berkembang dan mewujudkan penegakan hukum, tertib sipil dan stabilitas keamanan.

Kepentingan nasional yang juga ingin dicapai Presiden Duterte adalah kelangsungan hidup yang baik, keutuhan wilayah serta kesejahteraan bagi rakyatnya. Kekuasaan yang diduduki Presiden Duterte mendorong Duterte untuk menetapkan kebijakan ini guna menghilangkan dan mengkontrol negaranya dari kejahatan narkoba. Dalam bidang politik terdapat kepentingan jangka pendek, yaitu dalam rangka mewujudkan penegakan hukum di semua kalangan termasuk pejabat, mengingat kebijakan War on Drug juga berlaku bagi pejabat yang terlibat dalam tindak kejahatan narkoba. Menurut Duterte, pejabat yang melindungi tersangka tindak kejahatan narkoba merupakan bentuk yang paling nyata menjadi penghalang jalannya pembangunan dan wibawa pemerintah (McKirdy, 2016).

Sedangkan kepentingan jangka panjangnya adalah dalam upaya mewujudkan tertib sipil, wibawa pemerintah dan pembangunan yang berlanjut. Dalam bidang sosial-ekonomi, berdasarkan hasil survei yang dilakukan lembaga studi independen dalam Social Weather Station yang dilakukan pada bulan Maret 2017, menyebutkan bahwa terdapat sedikitnya 50 persen dari jumlah penduduk Filipina hidup dalam kemiskinan. Keadaan ini diduga ada hubungannya dengan tindak kejahatan narkoba sehingga kualitas produktifitas masyarakat Filipina, khususnya kaum muda menjadi menurun. Pada tahun 2014, publikasi UNDP melaporkan bahwa Filipina merupakan negara dengan kesenjangan antara ekonomi rakyat dan ekonomi internasional yang tinggi. Kemajuan Filipina bergantung dari sektor manufaktur dan jasa, sedangkan dalam sektor riil kontribusinya sangat rendah. Hal ini disebabkan karena lemahnya produktifitas masyarakat, terlebih kelas menengah hingga menengah ke bawah serta adanya hedonism dan tindak penyalahgunaan nakoba.

Command Memorandum Circular (CMC) No. 16 - 2016 adalah kerangka kerja kampanye Presiden Rodrigo Duterte. Dalam memorandum ini, dirancang kebijakan double barrel project yang memiliki dua cabang, yaitu Oplan Tokhang dan Oplan High Value Target (HVT). Kebijakan Oplan Tokhang ditandai sebagai pendekatan yang lebih rendah, dimana polisi mengunjungi rumah-rumah tersangka yang terlibat dalam menggunakan obat-obatan terlarang yang dibujuk agar menyerahkan diri kepada pihak yang berwenang untuk menjalani rehabilitasi. Oplan Tokhang disebut juga sebagai operasi hubungan antara masyarakat dan polisi. Sedangkan Oplan HVT yaitu operasi yang dilakukan Kepolisian Nasional Filipina yang ditujukan untuk menangkap dan menetralisir individu yang terlibat dalam perdagangan narkoba ilegal di Filipina yang di dalamnya termasuk bandar narkoba 
maupun individu yang beroperasi di dalam kelompok (Comand Memorandum Circular).

Dalam memorandum tersebut, Presiden Rodrigo Duterte menyerukan untuk menembak mati para pelaku apabila mereka melakukan perlawanan kepada petugas yang berwenang. Tetapi dalam pelaksanaan operasinya, yang seharusnya tersangka menyerahkan diri dan melakukan rehabilitasi justru yang terjadi adalah pembunuhan di luar hukum sehingga menyebabkan banyaknya kematian pelaku pengguna dan pengedar tindak kejahatan narkoba. Hal ini menyebabkan terjadinya pelanggaran hak asasi manusia. Sejak Juli 2016 hingga Maret 2017 tercatat sudah ada 8.000 tersangka pengedar narkoba yang terlapor tewas (Samosir, 2017), diantaranya adalah pembunuhan oleh penyerang yang tidak dikenal di bawah penyelidikan dan menurunnya tingkat kriminalitas di Filipina. Sebanyak 4.400 tersangka juga telah meyerahkan diri kepada pihak polisi, hal ini terjadi karena para pengedar dan pemakai narkoba tersebut merasa takut akan menjadi pembunuhan.

Kebijakan War on Drugs membuktikan adanya penurunan tingkat kriminalitas, yaitu sebanyak $13 \%$ terhitung semenjak Duterte menduduki jabatan Presiden Filipihan hingga bulan Juni 2016, tetapi juga menyebabkan orang-orang bisa dibunuh atau membunuh dengan sesukanya (Fadlia \& Ramadani, 2018). Ini merupakan bukti adanya pelanggaran Hak Asasi Manusia (HAM) yang terjadi di Filipina, dimana kebijakan yang diterapkan Presiden Rodrigo Duterte dalam upaya memerangi tindak kejahatan narkoba berujung dengan terampasnya HAM. Kebijakan Presiden Duterte dianggap sebagai solusi brutal tapi cepat dalam memberantas kejahatan di Filipina, dan diduga menyebabkan adanya kenaikan pertumbuhan ekonomi di negaranya. Dalam kebijakannya, Duterte menerapkan Drugs on War dimana akan membunuh langsung di tempat bagi siapapun pelaku tindak kejahatan narkoba. Sejak ditetapkannta kebijakan tersebut pada tahun pertama pemerintahan Presiden Duterte, sedikitnya terdapat 3.171 tersangka tindak kejahatan narkoba yang tewas dalam operasi polisi (DW Com, 2017).

\section{Pelanggaran HAM}

Dalam perspektif hukum internasional yang mengatur Hak Asasi Manusia, International Convenant on Civil and Political Rights dan Universal Declaration of Human Rights, kebijakan War on Drugs yang ditetapkan oleh Presiden Duterte telah menyebabkan terjadinya pelanggaran HAM. Negara-negara di dunia yang telah menerima dan menyepakati instrumen-instrumen yang terdapat pada UDHR dan ICCPR untuk menegakan HAM, memiliki kewajiban dimana setiap negara harus menjamin HAM yang dimiliki setiap warganya termasuk menghormati, melindungi dan memenuhi. Termasuk pemerintah Filipina, wajib bertanggung jawab atas hilangnya HAM yang dimiliki para tersangka tindak kejahatan narkoba yang dilakukan oleh pemerintah Filipina.

Pada pasal 6 ayat 1 dalam ICCPR menyatakan bahwa tidak ada dari setiap manusia yang dapat merenggut hak untuk hidup yang dimiliki setiap manusia lainnya secara sewenang-wenang. Hak yang telah melekat pada manusia dari sejak di kandungan ini wajib dilindungi oleh hukum (United Nations Human Rights, n.d.). 
Hukuman mati dengan menembak di tempat tersangka tindak kejahatan narkoba di Filipina, sangat berkaitan dengan hak hidup seseorang. Hilangnya ribuan nyawa akibat kebijakan War on Drugs yang dilakukan oleh Presiden Duterte tanpa adanya bukti bahwa orang tersebut bersalah dan diadili secara hukum berdasarkan putusan akhir pengadilan, dapat dikatakan bahwa kebijakan yang ditetapkan Presiden Duterte telah menyebabkan terjadinya kejahatan kemanusiaan dan melanggar HAM karena terkait dengan hak setiap individu untuk hidup dan hak yang berkaitan dengan proses pengadilan sebagaimana yang dinyatakan pada pasal 10 DUHAM, bahwa setiap individu memiliki persamaan yang penuh, memiliki hak atas peradilan yang adil, bebas dan secara terbuka dalam setiap tuntutan pidana yang akan dijatuhkan. Hal ini juga sebagaimana tercantum dalam Pasal 3 UDHR yang menyatakan bahwa setiap individu berhak atas kebebasan, penghidupan dan keselamatan.

Kemudian, pada pasal 9 UDHR disebutkan bahwa tidak ada satupun individu yang diperbolehkan ditangkap, ditahan ataupun diasingkan dengan semenamena. Ketentuan ini sangat bertentangan dengan apa yang terjadi di lapangan dalam pelaksanaan kebijakan War on Drugs. Aparat yang berwenang akan mendatangi rumah target tersangka narkoba tanpa memperkenalkan diri ataupun memperlihatkan surat penangkapan. Keluarga dari target penangkapan bisa mendengar, anggota keluarganya yang menangis, berteriak dan memohon ampun atas kesalahan yang belum pasti dilakukannya (Samosir, 2017). Penembakan juga sewaktu-waktu bisa terjadi, di dalam rumah, di jalan ataupun beberapa menit setelah keluar dari rumah dan setelahnya warga akan menemukan jasadnya.

Kebijakan War on Drugs Presiden Duterte menyatakan tidak pandang bulu dalam menerapkan kebijakannya dan akan mengesampingkan Hak Asasi Manusia. Bahkan, Duterte dengan tegas dan berani untuk mengidentifikasi adanya keterlibatan pejabat negara atau politisi dalam perdagangan narkoba. Duterte menilai bahwa pada pemerintahan sebelumnya telah menutup mata telah adanya pejabat negara yang ikut berpatisipasi dalam melindungi pelaku perdagangan narkoba (Lasco, 2017). Duterte juga memerintahkan aparat kepolisian agar meningkatkan upaya tegas dalam memberantas tindak kejahatan narkoba hingga tiga kali lipat. Hal ini dipandang sebagai pembunuhan dalam skala besar yang disetujui oleh negara.

Kebijakan Presiden Duterte ini mendapat banyak kecaman dari para penggiat Hak Asasi Manusia (HAM) dan masyarakat internasional. Mereka menanggapi bahwa kebijakan yang dibuat Presiden Duterte sama dengan kejahatan kemanusiaan, bahkan para penggiat HAM melakukan protes, demo di Filipina hingga pengajuan investigasi secara resmi oleh Badan Perserikatan Bangsa-Bangsa (PBB). Hal ini ditanggapi oleh Presiden Duterte dengan menyatakan bahwa jika tindak kejahatan narkoba dibiarkan, maka sama saja dengan membunuh nyawa itu sendiri dengan menggunakan narkoba (BBC News, 2018) dan Duterte beranggapan bahwa Duterte merupakan cerminan dari orang-orang yang memilihnya. 


\section{Tanggapan Masyarakat Filipina}

Terpilihnya Rodrigo Duterte menjadi Presiden Filipina adalah salah satu bukti kepercayaan masyarakat Filipina terhadap Rodrigo Durterte. Hal ini diperkuat dengan adanya survei yang dilakukan oleh Pulse Asia pada akhir September 2017. Survei tersebut menunjukan bahwa $80 \%$ dari 1.200 orang yang diwawancarai menyatakan menaruh kepercayaannya atas kepresidenan Duterte, sedangkan 6\% menyatakan tidak adanya kepercayaan dan sisanya $14 \%$ menyatakan ragu-ragu (Santos, 2017). Bahkan, beberapa orang dari sisa responden tersebut mendukung Duterte sebagai Presiden dalam isu-isu lain, misalnya agenda ekonomi yang dibuat Duterte relative progresif dengan focus pada ketimpangan ekonomi.

Berdasarkan survei tersebut, masyarakat kelas bawah, dimana kebanyakan menjadi pelaku tindak kejahatan narkoba, tidak menyetujui adanya kebijakan ini dikarenakan adanya kekahwatiran mereka jika sewaktu-waktu seseorang terdekatnya akan menjadi korban pembunuhan tanpa adanya proses hukum terlebih dahulu. Sedangkan masyarakat kelas atas menaruh penuh kepercayaannya atas kinerja Presiden Duterte dalam memberantas narkoba agar terjaminnya keamanan dari kejahatan dan narkoba (Mogato, 2017).

Sementara itu, survei lainnya menunjukan bahwa terdapat $76 \%$ masyarakat Filipina sadar bahwa adanya pelanggaran Hak Asasi Manusia dalam kebijakan War on Drugs (Asia Pacific Foundation Of Canada, n.d.). Dalam konteks kriminalitas dan kejahatan narkoba, adanya perang narkoba ini menunjukan hasil yang sangat signifikan tetapi tidak dapat dihindari juga bahwa pasokan narkoba tetap merajalela. Duterte juga memperoleh dukungan karena membuat program dan kebijakan anti kemiskinan. Duterte juga menganggap penting isu-isu ketimpangan sosial dan ekonomi. (Xiu, 2016). Hal ini membuat masyarakat Filipina yakin bahwa kebijakan War on Drugs yang dijalankan Presiden Duterte bukanlah perang dengan orang miskin.

Bisa disimpulkan bahwa sebagian besar masyarakat Filipina merasa puas dengan adanya kebijakan War on Drugs yang dilaksanakan Presiden Duterte, karena mereka merasa tingkat kejahatan di Filipina berkurang dengan adanya kebijakan ini walaupun sebenarnya mungkin mereka sadar akan adanya pelanggaran Hak Asasi Manusia.

\section{SIMPULAN}

Kebijakan War on Drugs yang ditetapkan Presiden Duterte merupakan tindakan yang melanggar Hak Asasi Manusia yang mengatasnamakan keamanan dan kepentingan nasional. Hal tersebut merupakan hal yang tidak bisa dibenarkan dalam hukum internasional. Walaupun banyak mendapat kritik dan kecaman dari pegiat HAM, bahkan dari masyarakat internasional, Presiden Duterte akan tetap melanjutkan kebijakannya. Presiden Duterte menyatakan akan mengesampingkan HAM karena dari kebijakannya tersebut, terbukti bahwa tingkat kriminalitas di Filipina menurun dengan sangat signifikan. Hal ini didorong dengan adanya 
kepercayaan masyarakat Filipina akan cara kerja Presiden Duterte walaupun dengan kekerasan.

Presiden Duterte dalam merumuskan kebijakan War on Drugs tentunya juga mempertimbangkan kepentingan nasional Filipina lainnya, yaitu kepentingan sosialekonomi dan politik. Dalam bidang politik, Presiden Duterte menginginkan adanya penegakan hukum yang secara merata, baik untuk masyarakat sipil maupun untuk pejabat pemerintahan, menertibkan sipil dan menjaga wibawa pemerintah. Sedangkan dalam bidang sosial-ekonomi, Presiden Duterte ingin membangun perekonomian karena setengah dari seluruh masyarakat Filipina hidup dalam kemiskinan. Presiden Duterte juga ingin menyelamatkan generasi muda bangsa dari kecanduan terhadap narkoba. Menurutnya, candu akibat narkoba juga merupakan salah satu yang mengancam keamanan manusia di negaranya.

\section{DAFTAR PUSTAKA}

Anthony, M. C. (2009). Challenging Change: Non Traditional Security, Democracy and Regionalism. ISEAS Publishing, 193-194.

Comand Memorandum Circular. (n.d.). PNP Anti Illegal Drugs Campaign Plan Project: Double Barrel. Retrieved from Comand Memorandum Circular No.16-2016: CMC 2016-16 PNP ANTI-ILLEGAL DRUGS CAMPAIGN PLAN PROJECT DOUBLE BARREL.pdf.

Drug Archive. (n.d.). The Official Document. Retrieved from Drug Archive: The Official Documents (drugarchive.ph).

DW Com. (2017, Juni 30). Perang Duterte Terhadap Narkotika dianggap Sukses. Retrieved from DW Com: Perang Duterte terhadap Narkotika Dinilai Sukses | DUNIA: Informasi terkini dari berbagai penjuru dunia | DW | 30.06.2017.

Fadlia, F., \& Ramadani, I. (2018). Perang Terhadap Narkoba ala Duterte (Analisis Political Culture). Jurnal Review Politik, Vol. 8 No.1. Retrieved from Perang terhadap Narkoba ala Duterte (Analisis Political Culture) | JRP (Jurnal Review Politik) (uinsby.ac.id).

Internasional Kompas. (2016, September 8). Davao Tanah Kelahiran Duterte. Retrieved from Internasional Kompas: Davao, Tanah Kelahiran Duterte Halaman all - Kompas.com.

Martono, L. H., \& Joewana, S. (2008). Belajar Hidup Bertanggung Jawab, Menangkal Narkoba dan Kekerasan. Jakarta: Balai Pustaka. 
McKirdy, E. (2016). Dead or Alive: Is the Philippines War on Drugs Out of Control? Retrieved from CNN.

Mogato, M. (2017, April 5). Philippines President Duterte's Trust rating Fall Slightly, Poll Shows. Retrieved from Jakarta Globe: Philippine President Duterte's Trust Ratings Fall Slightly, Poll Shows (jakartaglobe.id).

Moleong, L. J. (2014). Metode Penelitian Kualitatif. Bandung: Remaja Rosdakarya.

N., P. (2003). Cross-Border Crime and The Interface Between Legal and Ilegal Actors. Security Journal, Vol. 16 (1), 20.

Prayuda, R. (2020). Kejahatan Transnasional Terorganisir di Wilayah Perbatasan: Studi Modus Operandi Penyelundupan Narkotika Riau dan Malaysia. Andalas Journal of Internastional Studies, Vol IX No. 1, 35.

Samosir, H. A. (2017, Maret 3). HWR: Polisi Filipina Palsukan Bukti untuk Benarkan Pembunuhan. Retrieved from CNN Indonesia: HRW: Polisi Filipina Palsukan Bukti untuk Benarkan Pembunuhan (cnnindonesia.com).

Sugiyono. (2017). Metode Penelitian Kuantitatif, Kualitatif dan R\&D. Bandung: Alfabeta CV.

Saryono. (2010). Metode Penelitian Kualitatif. Bandung.

Suwarman, E. M. (2018). Rivalitas Geopolitik Amerika Serikat - Tiongkok di Myanmar. Journal Asia Pasific Studies, 182.

Santos, E. P. (2017, Oktober 13). Duterte Maintains High Approval, Trust Score Pulse Asia. Retrieved Juli 4, 2021, from CNN Phiippines: Duterte maintains high approval, trust scores - Pulse Asia (cnnphilippines.com)

Social Weather Station Survey. (2017, Mei 6). First Quarter 2017 Social Weather Survey: Net Trust in Rodyy Duterte Stays Excellant at+70. Retrieved from Social Weather Station Survey: Social Weather Stations | First Quarter 2017 Social Weather Survey: Net trust in Rody Duterte stays Excellent at +70 (sws.org.ph)

United Nations Human Rights. (n.d.). Universal Declaration of Human Rights. Retrieved from UHCHR: OHCHR |

World Drugs Report. (n.d.). United Nations Office on Drugs and Crime: Philippines Country Report. Retrieved from World Drugs Report: untitled (unodc.org) 
Xiu, M. (2016, Desember 16). Human Rights and Duterte's War on Drugs. Retrieved from Human Rights Watch: Human Rights and Duterte's War on Drugs | Council on Foreign Relations (cfr.org)

Yesaya, S. (2017). Konstruksi Konsep Hak Robert Nozick dan John Rawls (Sebuah Komparasi Pemikiran). Jurnal Humaniora Yayasan Bina Darma. 